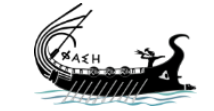

journal.phaselis.org
PHAS LLIS Issue V (2019)
Disiplinlerarası Akdeniz Araştırmaları Dergisi

Journal of Interdisciplinary Mediterranean Studies

\title{
Phaselis 2018 Yılı Güney Liman Alanı Sualtı Araştırmalarında Tespit Edilen Amphoralar
}

Phaselis Amphoras Detected in Underwater Surveys in South Harbor Area in 2018

\author{
Erdoğan ASLAN \\ (D) https://orcid.org/0000-0002-3437-7207 \\ Uğurcan ORHAN \\ (D) https://orcid.org/0000-0003-4344-6267
}

open 2 access journals

The entire contents of this journal, Phaselis: Journal of Interdisciplinary Mediterranean Studies, is open to users and it is an 'open access' journal. Users are able to read the full texts, to download, to copy, print and distribute without obtaining the permission of the editor and author(s). However, all references to the articles published in the e-journal Phaselis are to indicate through reference the source of the citation from this journal.

Phaselis: Journal of Interdisciplinary Mediterranean Studies is a peer-reviewed journal and the articles which have had their peer reviewing process completed will be published on the web-site (journal.phaselis.org) in the year of the journal's issue (e.g. Issue IV: JanuaryDecember 2018). At the end of December 2018 the year's issue is completed and Issue V: January-December 2019 will begin.

Responsibility for the articles published in this journal remains with the authors.

Citation E. Aslan - U. Orhan, "Phaselis 2018 Yılı Güney Liman Alanı Sualtı Araştırmalarında Tespit Edilen Amphoralar". Phaselis V (2019) 85-99. http://dx.doi.org/10.18367/Pha.19004

Received Date: 19.01.2019 | Acceptance Date: 26.02.2019

Online Publication Date: 22.03.2019

Editing Phaselis Research Project

www.phaselis.org 


\title{
Phaselis 2018 Yılı Güney Liman Alanı Sualtı Araştırmalarında Tespit Edilen Amphoralar
}

\author{
Phaselis Amphoras Detected in Underwater Surveys in South Harbor Area in 2018
}

\author{
Erdoğan ASLAN* - Uğurcan ORHAN**
}

\begin{abstract}
Öz: Phaselis Güney Liman Alanı́nda 2018 yılı yüzey araştırmaları kapsamında sualtı araştırmaları gerçekleştirilmiştir. Yapılan sualtı araştırmalarında Güney Liman Havzası içerisinde, mimari yapı parçaları, metal objeler, çatı kiremitleri, taban döşemeleri, pişmiş toprak kaplar ve çok sayıda amphora parçası tespit edilerek belgelenmiştir. Sualtında belgelenen amphoralar ise çalışmanın konusunu oluşturmaktadır. Söz konusu amphoralar, köken ve form açısından incelenerek tarih önerilerinde bulunulmuştur. Bir batığa ait ya da in-situ durumda olmayan bu amphora parçalarının çizimleri ve detaylı tanımları yapılmış, benzerlerinden yola çıkılarak tarih önerilerinde bulunulmuştur. Bu kapsamda yedi farklı amphora formunun beş farklı kökene ait olduğu tespit edilmiştir. Çalışmanın en erken tarihli amphorasını, Mısır kökenli MÖ III. yüzyılın son çeyreği ile MÖ II. yüzyılın ilk çeyreğine tarihlenen AE 1-A formu oluşturmaktadır. En geç tarihli örnek ise Marmara kökenli MS 12.-13. yüzyıla tarihlenen Günsenin (Ganos) tip IV amphorasıdır. Güney Liman Alanı'nda tespit edilen bu amphoraların ilk kez tarafımızca çalışııı̧ olması ve Güney Liman'ın ticari fonksiyonlarının belirlenmesinde amphoraların köken ve tarihlerinin kriter olarak ele alınması ayrıca önem arz etmektedir.
\end{abstract}

Anahtar sözcükler: Phaselis, Güney Liman, Sualtı Araştırmaları, Ticari Amphoralar

Abstract: Underwater surveys were conducted in Phaselis South Harbor Area in 2018. In the underwater surveys, architectural components, metal objects, roof tiles, floor tiles, terracotta pots and numerous amphora fragments were identified and documented in the South Harbor Area. The amphorae documented underwater are the subject of the study. These amphoras were examined in terms of origin and form and suggestions for history were made. These amphoras, which do not have any shipwerck or in-sutu finds, have been made date suggestions and detailed drawings and detailed explanations have been made. These amphoras, which do not have any context or in-situ finds, have been proposed for their dates and detailed drawings and detailed descriptions have been made. In this context, seven different amphora forms were found to belong to five different origins. The earliest amphora of the study was the AE 1-A form of Egyptian origin dating to the last quarter of the $3^{\text {rd }}$ century $B C$ and the first quarter of the $2^{\text {nd }}$ century BC. The latest example is the Marmara originated Günsenin (Ganos) type IV amphora dated to the $12^{\text {th }}-13^{\text {th }}$ century AD. The fact that these amphoras found in the South Harbor Area were first studied by us and the origin and dates of the amphoras as a criterion in determining the commercial functions of the South Harbor are also important.

Keywords: Phaselis, South Harbor, Underwater Research, Commercial Amphoras

* Doç. Dr., Selçuk Üniversitesi, Edebiyat Fakültesi, Arkeoloji Bölümü, Konya, erdoganaslan@gmail.com (D) https://orcid.org/0000-0002-3437-7207

** Ph.D., Akdeniz Üniversitesi, Akdeniz Uygarlıkları Araştırma Enstitüsü, Akdeniz Eskiçağ Araştırmaları Anabilim Dalı, Antalya, orhanugurcan@gmail.com (D) https://orcid.org/0000-0003-4344-6267 
Giriş

Phaselis Antik Kenti, günümüzde Antalya ili, Tekirova İlçesi sınırları içerisinde yer almakta olup, üç adet doğal liman ile bir de demirleme alanına sahiptir ${ }^{1}$. Ayrıca söz konu limanları sayesinde Phaselis'in, bir liman kenti statüsünde olduğu birçok kaynakta belirtilmektedir². Phaselis ve Teritoryumu Yüzey Araştırmaları kapsamında³, 2018 yıllında liman araştırmalarına paralel olarak gerçekleştirilen sualtı araştırmaları sürdürülmüş̧ ${ }^{4}$ ayrıca Güney Liman Alanı da araştırma sahasına dâhil edilmiştir ${ }^{5}$. Bu kapsamda 5 ile 18 metre arası değişen derinliklere sahip Güney Liman Alanı'na scuba dalışlar gerçekleştirilmiştir (Fig. 1).

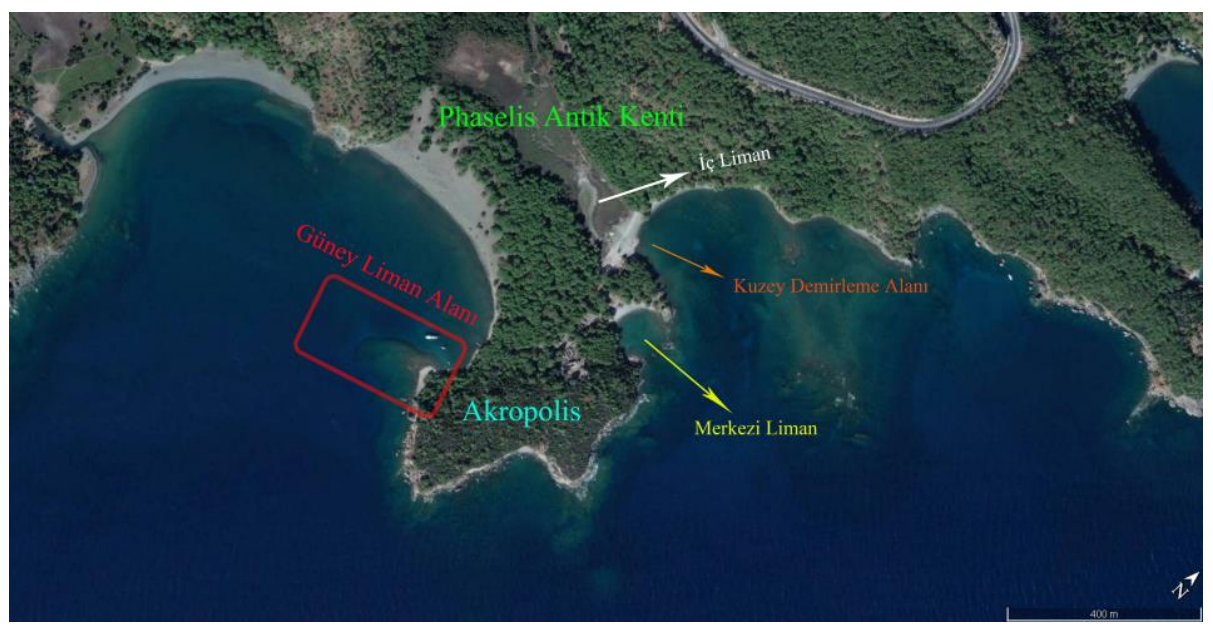

Fig. 1. Phaselis Antik Kenti Google Earth Haritası

Yapılan dalışlarda mimari yapı elemanları, metal objeler, çatı kiremitleri, taban döşemeleri, pişmiş toprak kaplar ve kırık amphora tespit edilerek belgelenmiştir. Kırık şekilde tespit edilen amphoraların yanı sıra formu saptanabilir nitelikte olan amphoralar bu çalışmanın ana materyalini oluşturmaktır. Sualtında tespit edilen söz konusu amphoraların, kökenlerinin saptanması, formların sınıflandırılması ile tarih önerilerinde bulunularak Güney Liman Alanı'nın ticari fonksiyonu ve kullanım evreleri anlaşılmaya çalışılmıştır. Bu kapsamda Güney Liman Alanı́nın farklı yerlerinde, beş farklı bölgeye ait toplam yedi farklı amphora formu tespit edilmiştir (Fig. 2).

Bu amphoralar; bir adet Tunus kökenli Afrika II-A, bir adet Mısır kökenli AE 1-A, bir adet Kilikya kökenli M 239 ve bir adet LR 1-A Adalar kökenli bir adet Samos Cistern (Sarnıç) tipi ve Marmara kökenli dört adet Günsenin (Ganos) Tip I ile bir adet Tip IV amphoralarıdır. Sözü geçen amphoraların tümü sualtında fotoğraflanarak dijital ortamda çizimleri yapılarak tanımlanmıştır. Fakat çalışmanın sualtında gerçekleştirilmiş olması, sualtında çalışma süresinin kısıtlı olması ve izinler gereği amphoralara fiziksel müdahalenin yapılamaması çalışmanın zorluğunu teşkil etmektedir. Nitekim amphora tipolojisi konusunda petrografik analizler ve renk kodları, köken-

Liman Araştırmaları için ayrıca bk. Aslan-Baybo 2015, 1-17; Aslan 2016, 31-47; Aslan et al. 2018, 1-13; ArslanTüner Önen 2018, 295-323.

Tüner-Önen 2008, 17-19.

Arslan et al. 2013, 224-229; Arslan-Tüner Önen 2013, 78-89; Arslan 2018, 15-47.

Bu makalenin konusunu oluşturan çalışma, Selçuk Üniversitesi Bilimsel Araştırma Projeleri Koordinatörlüğü tarafından desteklenmiştir (Proje no. BAP: 17401021)

2013 yılından itibaren Prof. Dr. Murat Arslan başkanlığında sürdürülen Phaselis Antik Kenti ve Teritoryumu Yüzey Araştırmaları kapsamında, Doç. Dr. Erdoğan Aslan tarafından Phaselis Limanları ve çevresine yönelik arkeolojik sualtı çalışmaları yürütülmektedir. Sualtı çalışmalarını gerçekleştirmemiz için araştırma heyetine bizleri dâhil eden Phaselis Antik Kenti ve Teritoryumu Yüzey Araştırmaları Başkanı Prof. Dr. Murat Arslan ve ekibine teşekkür ederiz. 
lerinin ve üretim yerlerinin tespit edilmesinde önem arz etmektedir. Belgelemenin tamamının sualtında yapılmış olması nedeniyle derinliğe bağlı olarak yaşanan renk kayıplarından dolayı bu veriler elde edilememiştir. Çalışmada yer alan amphoralar form özelliklerine göre değerlendirilerek benzerleri ile karşılaştırılıp tarihlendirilmiştir.

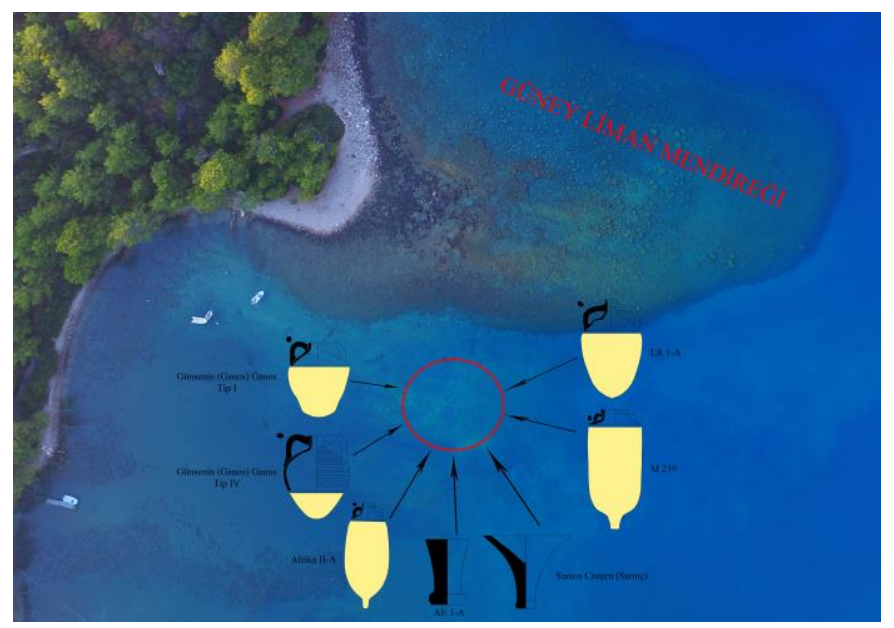

Fig. 2. Güney Liman Alanı ve Amphora Buluntu Yerleri

\section{AE 1-A Amphorası}

AE 1 amphoraları, Hellenistik Dönem'de Mısır'ın Delta Bölgesi'ndeki alanlarda, özellikle Mareotis Gölü'nün güneyinde yer alan atölyelerde üretilmiştir ${ }^{6}$. Ayrıca bu bölgelerde yapılan araştırmalarda çok sayıda atık seramik çöplüklerine ve üretim atölyelerine rastlanılmış, AE 1 amphoralarının devamı niteliğinde farklı amphora tiplerine de ulaşılmıştır . Hellenistik Dönem' de Mısır'da üretilen ilk amphora formları olan AE 1 amphoralarının bazıları üzerinde mühürler bulunmaktadır ${ }^{8}$ Büyük boyutlarda ve yüksek kapasiteleri ile karşımıza çıkan AE 1 amphoralarında, Mısır'ın şarabı, Akdeniz piyasasına kazandırılmaya çalışılmıştır ${ }^{9}$. MÖ III. yüzyıldan itibaren AE 1 amphoralarında taşınan şarap, lokal bir dağılım göstermekle birlikte bölge dışı olarak Kıbrıs'a ihraç edildiği bilinmektedir10. Kıbrıs'a ihracının yanı sıra Kilikya Bölgesi'nde yer alan Nagidos'ta yapılan kazılarda da az sayıda bu tipe ait kulp, boyun ve dip parçaları ele geçmiştir11. Bu kapsamda genel olarak dağııııına bakıldığı zaman ihracatın bölgesel kaldığı görülebilmektedir12.

Phaselis Güney Liman Alanı'nda tespit edilen AE 1 amphorasının sadece dip kısmı günümüze kadar koruna gelmiştir. Bu tip amphoralar form olarak; dışa çekilmiş bant formunda ağız kenarına, silindirik, çok geniş olmayan bir boyna, ağızın hemen altından başlayarak omuz üzerinde gövdeyle birleşen oval kesitli kulplara, omuz bölümünde itibaren genişleyen geniş bir gövdeye, içi dolu altı düz bir dibe sahiptir.

Bu tipin benzerleri, Nagidos'ta yapılan kazılarda ele geçen örnekler MÖ IV. yüzyıl sonları ile MÖ III. yüzyııın ilk çeyreğine ${ }^{13}$, İskenderiye Greko-Roman Müzesi'nde MÖ III. yüzyıl sonu II. yüzyıl

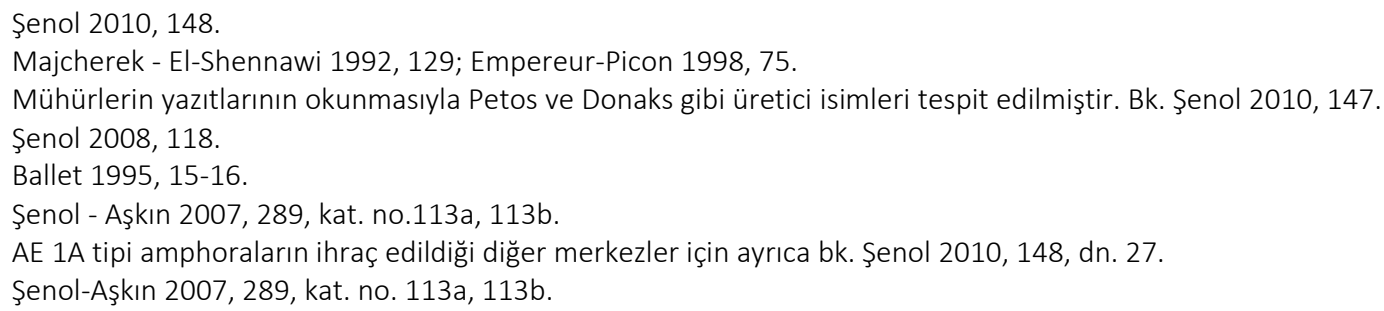


başına ${ }^{14}$, Taşucu Arslan Eyce Amphora Müzesi'ndeki benzeri ise MÖ III. yüzyıl sonu, MÖ II. yüzyıl başlarına tarihlendirilmiştir15. Çalışmamızda yer alan AE 1 amphorasının alt tipi olan A formu için benzerlerinden yola çıkılarak, MÖ III. yüzyılın son çeyreği ile MÖ II. yüzyılın ilk çeyreği arasında kalan tarihler önerilmektedir16 (Fig. 3).
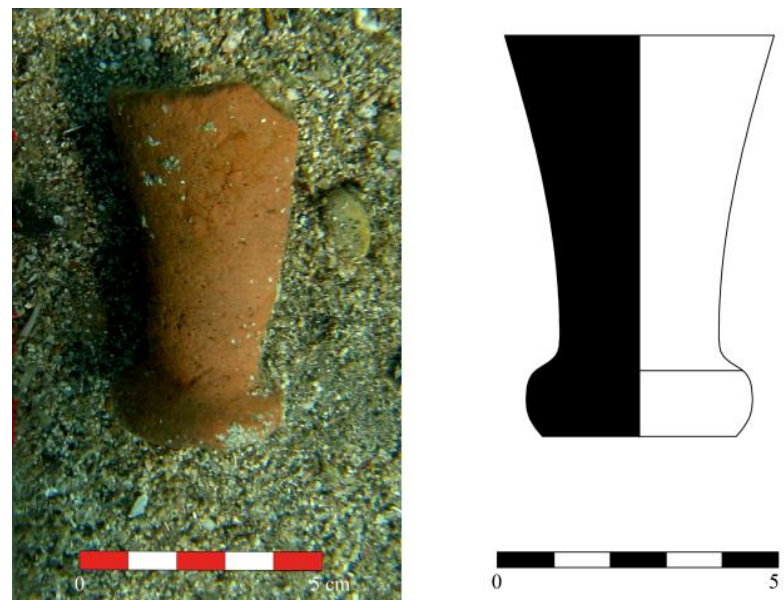

Fig. 3. AE 1-A Amphorası

\section{Afrika II-A}

Keay IV-VII, Peacock-Williams Class 34, Bonifay 26, Ostia III, Beltran 56 gibi farklı isimlerle de anılan bu tipe ait amphoralar, literatürde Afrika II olarak anılmaktadır ${ }^{17}$. Afrika II amphoralarına ait formlar, Panella tarafından dört alt grupta incelenmiştir18. Afrika II tipi amphoranın A, B, C ve D olarak incelenen alt formlardan, Afrika II-A oldukça geniş gövdeye, silindirik boyun ve oval kulplara sahiptir. Afrika II-B ve II-C, II-A formuna göre daha konik bir boyuna sahip, dar gövdeli ve kulpları köşelendirilmeye başlanmış, Afrika II-D ise, ağız kenarındaki dikeyleşen kenar ile diğer alt tiplerden ayrılmaktadır ${ }^{19}$.

MS II. yüzyıl sonlarına doğru20 üretime başlandığı düşünülen Afrika amphoraları üzerine yapılan analizlerde, kökeninin Afrika (Tunus) Byzacena, Sehel bölgesinde Hadrumentum, Leptis Minor, Sellectum, Thaenae veya Qued El-Akarit'de üretildiği düşünülmektedir21. Roma'da yapılan kazılarda Afrika II-A ve II-B amphoraları ele geçmiş ve konteksleri yardımıyla MS II. yüzyıldan daha erken bir zaman dilimi olan MS I. yüzyııın sonlarına tarihlendirilmiştir22. Geniş bir yayılıma sahip olan bu amphoralar, Batı Akdeniz'de bulunan merkezler başta olmak üzere, Doğu Akdeniz'deki birçok merkeze de ihraç edilmiştir23. Ayrıca Sadece Batı ve Doğu Akdeniz'de değil Atina, Almanya, Fransa ve İngiltere'ye kadar Afrika II amphoraları dağılım göstermektedir24. Batı Akdeniz'den Doğu Akdeniz'e kadar geniş bir alana dağılımı söz konusu olan bu amphoralarda

Şenol 2008, 118-130, fig. 6; Şenol 2009, 49; Şenol 2010, 148, fig. 2.

15 Şenol 2009, 264, env. no. T150.

16 Benzer tipli AE 1 amphoralarının tarihleme önerileri için ayrıca bk. Majcherek - El-Shennawi 1992, 129-133, fig. 3; Empereur-Picon 1998, 75-77, Fig. 2.

17 Bezeczky 2013, 154.

18 Panella 1973, 580-590.

19 Peacock - Williams 1986, 155.

20 Afrika Il amphoralarının A ve B formları, bu grubun en erken üretimli amphoralarıdır. Bk. Williams - Carreas 1995, 247.

21 Keay 1984, 123-126.

22 Williams - Carreas 1995, 247.

23 Panella 1973, 589.

24 Bonifay 2004, 111. 
başta şarap olmak üzere zeytinyağı ve balık sosu taşınmaktadır25.

Çalışmamızda tekil olarak tespit edilen Afrika II-A tipi amphoranın ağzı, boynu ve tek bir kulbu korunmuştur. Afrika II-A tipi amphoralara form olarak bakıldığında; dışa doğru genişletilerek yuvarlatılış ağız kenarına, ağız bitiminin hemen altından başlayarak omuzda birleşen oval kesitli kulplara, geniş, kısa bir boyuna, uzun, geniş, ovoidal gövde yapısına ve sivri şekilde uzatılmış dibe sahiptir.

Bu tipin benzerleri Williams tarafından MS II.-III. yüzyıla26, Riley Tarafından MS IV. yüzyıl sonuna ${ }^{27}$, Istres Müzesi'ndeki benzerleri MS III. yüzyıl sonu MS V. yüzyıl başına ${ }^{28}$, Sicilya'da Plemmirio yakınlarında tespit edilen bir Roma batığındaki benzeri MS 200 yılına tarihlendirilmiştir ${ }^{29}$. Çalışmamızda yer alan Afrika II-A amphorası, Bonifay'ın yaptığı sınıflandırmaya göre Afrika II A-4 alt sınıfına dâhil olmakta ve MS II. yüzyıl sonu III. yüzyıl başlarına tarihlenmesi önerilmekte$\operatorname{dir}^{30}$ (Fig. 4).

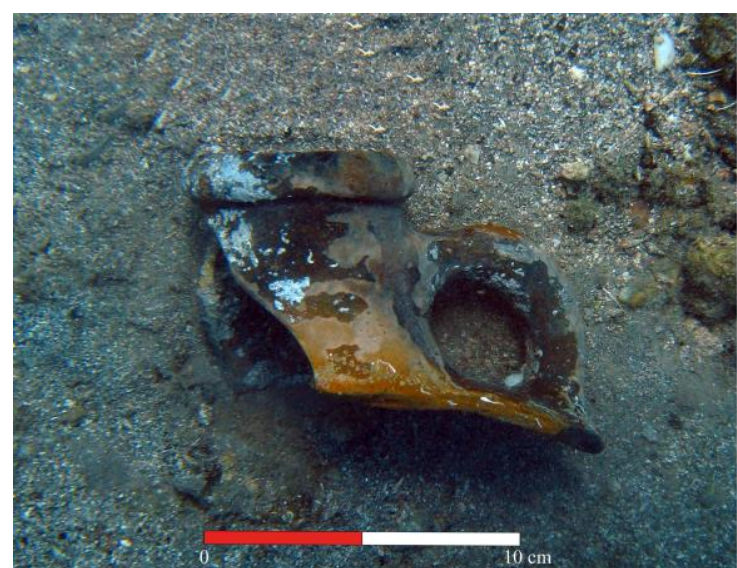

Fig. 4. Afrika 2-A Amphorası

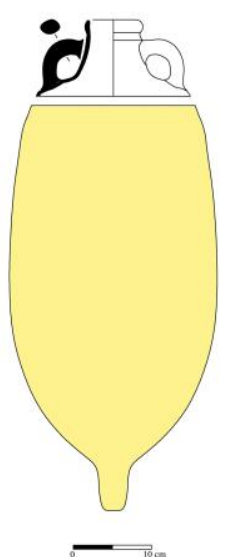

\section{239 Amphorası}

Atina Agorası'nda yapılan kazılarda ele geçen ve buluntu numaralarına göre ismini alan M 239 amphorası11, Zemer 41 amphorası ${ }^{32}$ ile form olarak yakın benzerlik göstermesi, bu amphoraların birbirlerine yakın bölgede üretilmiş olduğunu düşündürmektedir. Bu form, Dağlık Kilikya'da yapılan yüzey araştırmalarında, atık seramik tabakalarında ele geçmiştir33. Söz konusu bölgede, Syedra, Deli Çay ve Bıçkıcı Çay'ın fııın kalıntılarında ise Zemer 41 amphoralarına ait parçalar ele geçmiştir34. Üretim yeri olarak yakın yerlerde üretilen bu iki tip amphoranın, birbirinin devamı niteliğinde olduğu düşünülmektedir. Zemer 41 'in daha geç versiyonu olarak değerlendirilen $\mathrm{M}$ 239 amphorası, kapasitesi 2 litre kadar olup, bu tip minyatür amphoraların içinde özel reçineli şarabın dışında daha pahalı ürünlerinde taşınmış olabileceği öngörülmektedir ${ }^{35}$. İskenderiye'de

25 Peacock - Williams 1986, 156; Sibella 2002, 13; Bonifay 2004, 117.

26 Williams - Carreas 1995, 243-247, fig. 2.8-10.

27 Riley 1979.

28 Sciallano - Sibella 1991, 81.

29 Gibbins 2001, 318-319, fig. 5.d-e.

30 Bonifay 2004, 109-111, fig. 58.11.

31 Robinson 1959, pl. 28 M 239.

32 Zemer 41 amphorası için bk. Zemer 1977, 52 no. 42; Rauh et al. 2006, 53-57.

33 Şenol-Kerem 2000, 96.

34 Rauh 1998, 341.

35 Şenol 2009, 141. 
gerçekleştirilen kurtarma kazılarında, özellikle Eski Diana Tiyatrosu'nda ele geçen MS V. ve VI. yüzyıllarda ufak boyutta üretilmiş Geç Spatheia örnekleri söz konusu duruma örnek olarak gösterilebilmektediris.

Kilikya Bölgesi'nde, Paphos'ta (Kıbrıs), Ostia'da ile Popmei'de (italya) ve Suriye Filistin bölgesinde bulunmuş batıklarda yoğun olarak bulundukları bilinmektedir37. Doğu Akdeniz'de yoğun olarak kullanım gören Zemer 41 amphoralarıyla birlikte M 239 amphorası, Kuzey Afrika'da MS III. ve IV. yüzyıllar arasına tarihlenen tabakalarda ele geçmiştir38.

Phaselis Güney Liman içinde tespit edilen M 239 tipi amphoranın ağzı, boynu ve kulplarından biri günümüze kadar koruna gelmiştir. Bu amphora form olarak; dışa çekilerek, yuvarlatılmış ağız kenarına, kısa, geniş boyna, yivli kulplara, silindirik yivli bir gövdeye sahip olup gövdenin altında ise kaidesi mevcuttur. Korinthos'da yapılan kazılarda M 239 amphorasına ait örnekler MS III. yüzyıl ve MS VI. yüzyıl sonuna tarihlenen tabakalarda ele geçmiştir ${ }^{39}$. Bu amphoranın benzer örnekleri Atina Agorası'nda MS IV. yüzyılın sonu40 Silifke Müzesi MS IV. yüzyı|41, Mersin(İçel) Müzesi'nde ise MS IV. yüzyılın ortalarına tarihlendirilmiştir42. Çalışmamızda tespit edilen M 239 amphorası için ise MS IV. yüzyılın ortaları önerilmektedir (Fig. 5).
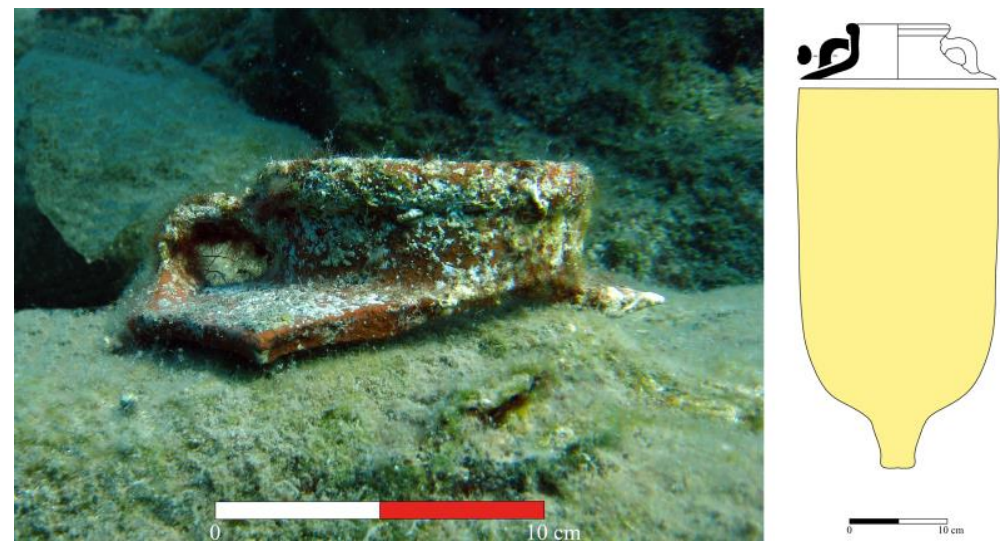

Fig. 5. M 239 Amphorası

\section{LR 1-A Tipi Amphora ${ }^{43}$}

LR 1 amphoralarına köken olarak bakıldığı zaman birçok bölgede üretildiği görülmektedir. Nitekim Kilikya Bölgesinde ve Kıbrıs'ta bu tipe ait amphora atölyeleri tespit edilmiştir ${ }^{44}$. Kilikya Bölgesi'nde yapılan bazı yüzey araştırmalarında yoğun olarak bu amphora tiplerine rastlanıımıştı ${ }^{45}$. Ayrıca Kıbrıs'ta gerçekleştirilen yüzey araştırmalarında da LR 1 amphoraları ele geçmiştir. Özellikle Kilikya Bölgesi sınırlarında yer alan Elaiussa Sebaste ile Seleukeia Pieria

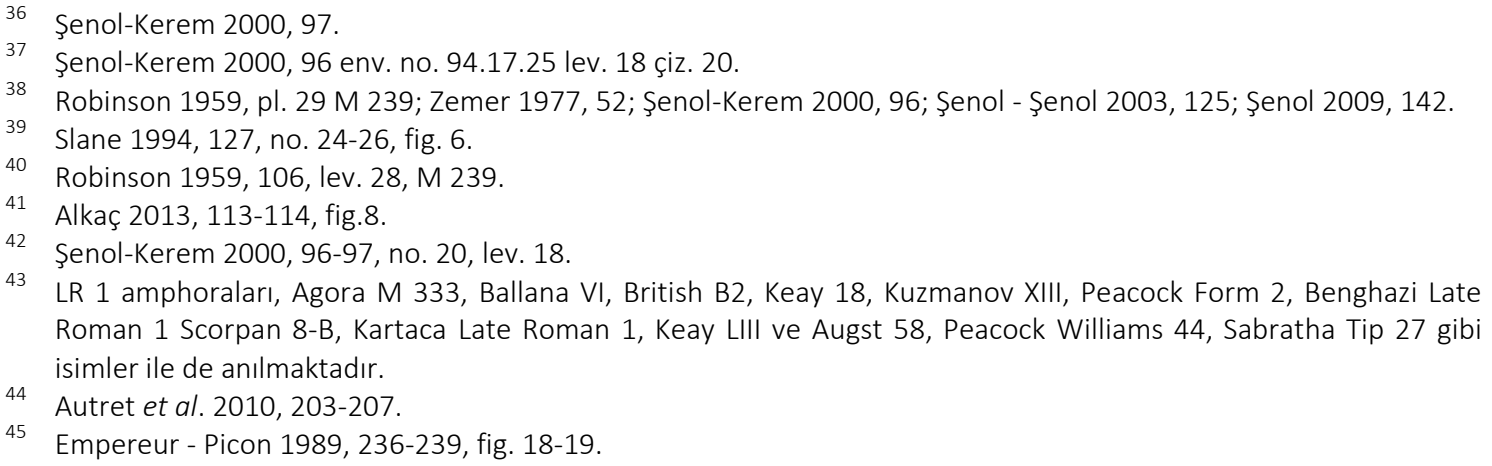

LR 1 amphoraları, Agora M 333, Ballana VI, British B2, Keay 18, Kuzmanov XIII, Peacock Form 2, Benghazi Late Roman 1 Scorpan 8-B, Kartaca Late Roman 1, Keay LIII ve Augst 58, Peacock Williams 44, Sabratha Tip 27 gibi isimler ile de anılmaktadır.

44 Autret et al. 2010, 203-207.

45 Empereur - Picon 1989, 236-239, fig. 18-19. 
arasındaki bölgede ve Yumurtalık Körfezi etrafında LR 1 amphoralarının atık seramik tabakaları tespit edilmiştir46. Ayrıca Kilikya Bölgesi sınırları içerisinde47, son yıllarda yapılan çalışmalarda Domuz Burnu ve Ayaş Hotel civarında LR 1 seramik işlikleri tespit edilmiştirr8. Sadece Kilikya Bölgesi ve Kıbrıs'da üretilmeyen bu amphoralar daha birçok bölgede üretim atölyelerinin olduğu saptanmış, farklı tarihlerde Rhodos, İçmeler, Magarsos, Aigia, Antiocheia, Kourion, Amathous gibi birbirinden farklı bölgelerde söz konusu amphoranın üretim atölyelerine rastlanılmıştır49.

Doğu Akdeniz'de bulunan bazı merkezlerde yapılan kazılarda ele geçen LR 1 amphoraları, bu merkezlerin dışında, Batı Akdeniz'de İspanya, İtalya, Tunus, Galler, güneybatı İngiltere, Anadolu'da özellikle İstanbul'da yapılan kazılar ve Karadeniz bölgesine kadar geniş bir yayılım göstermektedir50. LR 1 amphoraları ile taşınan ürünlere bakıldığı zaman zeytinyağı karşımıza çıkmaktadır51. Ayrıca zeytinyağının yanı sıra bu tip amphoralarda şarapta taşındığı bilinmektedir52. Üretildiği dönemler boyunca geniş bir yayılım ağına sahip olan bu tipe ait amphoraların içinde, sadece anlatılan ticari ürünler değil ayrıca baharatlar ve tekstil ürünlerinin de taşındığı belirlenmiştir53.

Çalışmamızda Güney Liman Alanı içinde tespit edilen bu amphoranın ağız, boyun ve kulpların bir kısmı günümüze kadar koruna gelmiştir. Yüzeyi yer yer kekomoz kaplı olan LR 1-A amphorası form olarak; dışa çekilerek yuvarlatılmış ağız kenarına, dudağın hemen altından başlayarak omuzda birleşen oval kesitli kulplara, ovoidal gövdeye ve küçük bir çıkıntı yapan dip yapısına sahiptir. Ayrıca üzeri sık yivler ile kaplıdır.

Bu tipin benzerleri; MS V. yüzyılda Gallia'ya ihraç edildiği belirlenen54 LR 1-A amphorası, Kekova Adası'nda tespit edilen LR 1-A amphorası MS IV-V. yüzyıla tarihlenmiştir55. Arslan Eyce Taşucu Amphora Müzesi'nde benzeri MS V. yüzyıla56, Marmaris Müzesi'nde ki benzeri MS V-VI. yüzyı|57 tarihi uygun görülmüştür. Kekova Adası'nda yapılan bir başka çalışmada ise benzer formlu LR 1-A amphorası MS V. yüzyıla tarihlendirilmiştir58. Çalışmamızda yer alan LR 1 amphoralarının alt grubu olan ve en erken üretim tarihli $A$ formu için benzerlerinden yola çıkılarak, MS V. yüzyıl tarihi önerilmektedir (Fig. 6).

\section{Samos Cistern (Sarnıç) Tipi Amphora}

İsmini üretildiği Samos (Sisam) Adası'ndan alan bu form, Ada üzerinde yer alan bir sarnıçta yapılan kazılarda ele geçmiştir59. Bu alanda çok sayıda Samos Cistern (Sarnıç) tipi amphoranın ele geçmesi, üretim merkezi olarak Samos Adası olduğu görüşünü kuvvetlendirmiştir60. Yapılan çalışmalarda bu tip amphoranın sadece Samos Adası'nda üretilmediği aynı zamanda Doğu

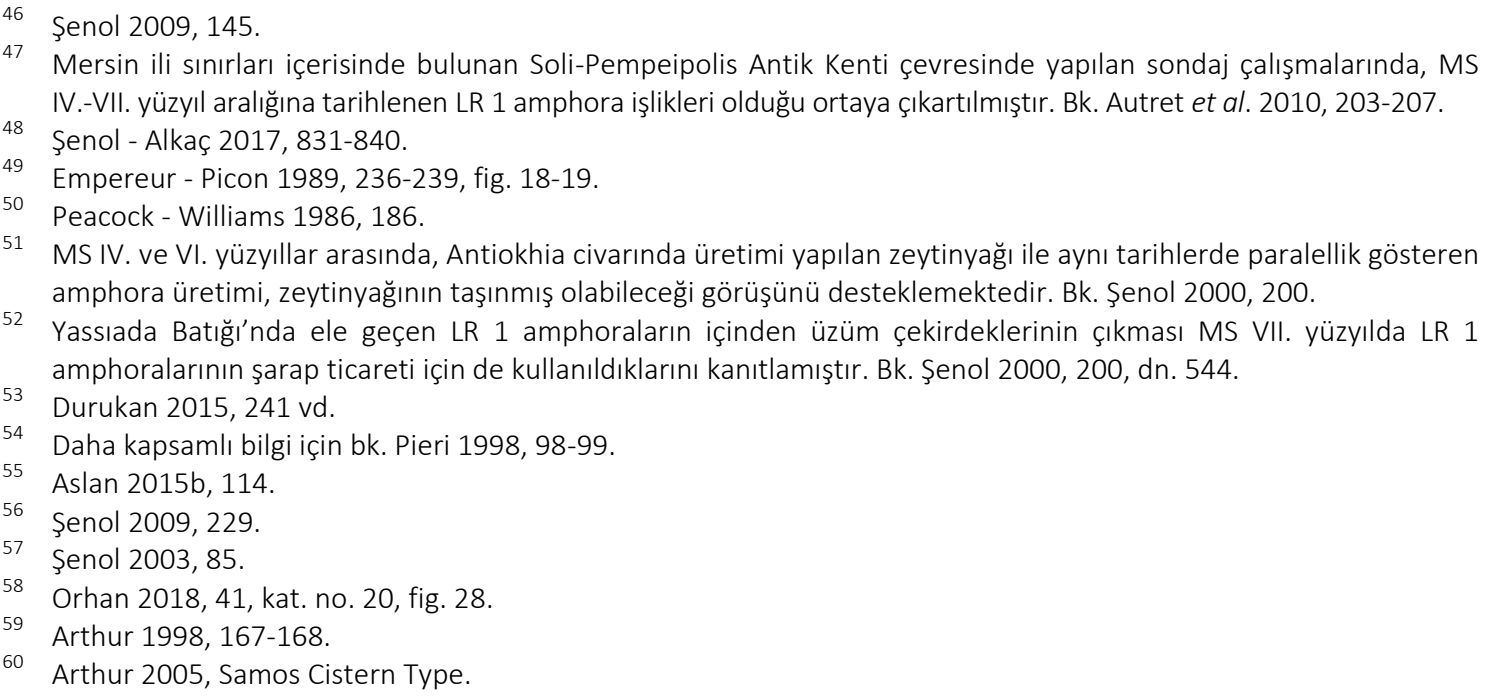


Akdeniz'deki bazı merkezlerde ve Halikarnassos'ta üretildiği ortaya konmaktadır61. Ayrıca Smyrna'nın kuzeyinde yapılan yüzey araştırmalarında, Elea limanında benzer Samos Cistern (Sarnıç) tipi amphoraların üretildiği tespit edilmiştir62.
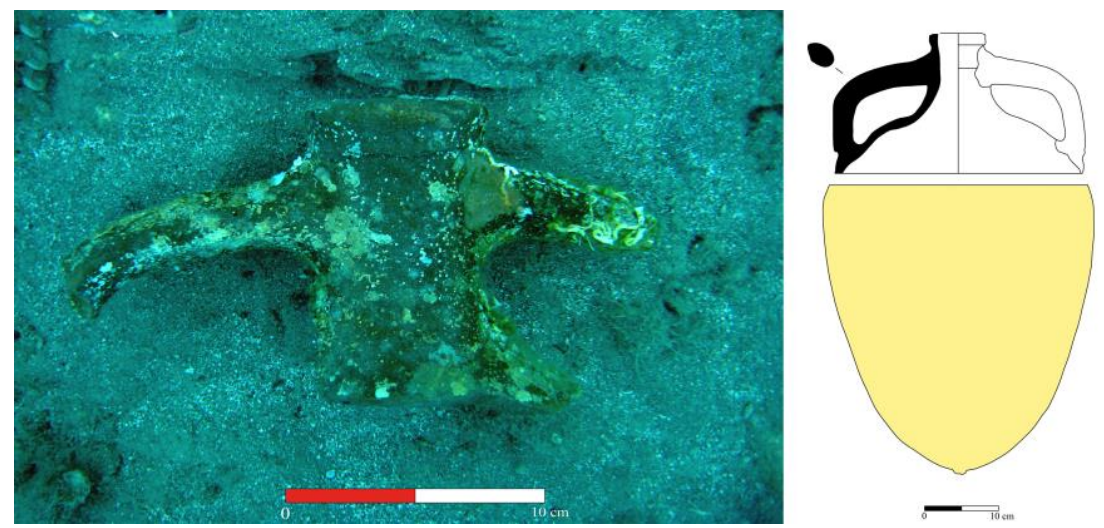

Fig. 6. LR 1-A Tipi Amphora

Geniş bir yayılım alanına sahip bu tip amphoralar, özellikle Anadolu'nun batı ve güney kıyıları olmak üzere, İtalya (Napoli), Marsilya, Karadeniz kıyıları, Balkanlar ve Trakya'daki merkezlere dağııım göstermektedir63. İçlerinde taşınan ürün hakkında kesin kanıtlar olmamasına rağmen şarap taşındığı düşünülmektedir64.

M 273 amphorasının devamı şeklinde üretildiği düşünülen Samos Cistern (Sarnıç) tipi amphoralar MS IV. yüzyılın ortalarından VII. yüzyılın sonlarına kadar üretildiği düşünülmektedir65. Üretildiği dönemler içerisinde form değişikliklerine maruz kalan bu tip amphoraların erken örnekleri şişkin bir gövde ve sert bir kaide geçişi ile altı düzleştirilmiş dibe sahipken daha geç örneklerinde gövdenin daraldığı, kaide geçişinin yumuşatıldığı ve dip kısmın sivriltildiği görülmektedir66. Çalışmamızda Güney Liman Alanı'nda tespit edilen Samos Cistern (Sarnıç) tipi amphoranın sadece dip kısmı günümüze kadar korunabilmiştir. Bu tip amphoralar form olarak; ucu sivriltilerek dışa çekilmiş ağız kenarına, geniş-kısa boyuna, dudağın hemen altından başlayarak omuzda birleşen oval kesitli dikey kulplara, boyundan başlayarak kaideye kadar uzanan yivli silindirik bir gövdeye, içi dolu sivri biçimli bir kaideye sahiptir.

Bu tipin benzerleri; Taşucu Müzesi'nde (AETAM) MS IV.-V. yüzyıl ve MS V.-VI. yüzyıllara67, Alanya Müzesi'nde MS VII. yüzyıla68, Kekova Sualtı Araştırmalarında MS V.-VII. yüzyıl arasına69, Knidos Sualtı Araştırmalarında benzer tarihler olan MS V.-VII. yüzyıl aralığına70, Elaiussa Sebaste'de ele geçen diğer bir benzeri ise Geç Roma- Erken Bizans Dönemi'ne tarihlendirilmiştir ${ }^{71}$. Çalışmamızda yer alan Samos Cistern (Sarnıç) tipi amphora, Ephesus'ta72 ve Elaiussa

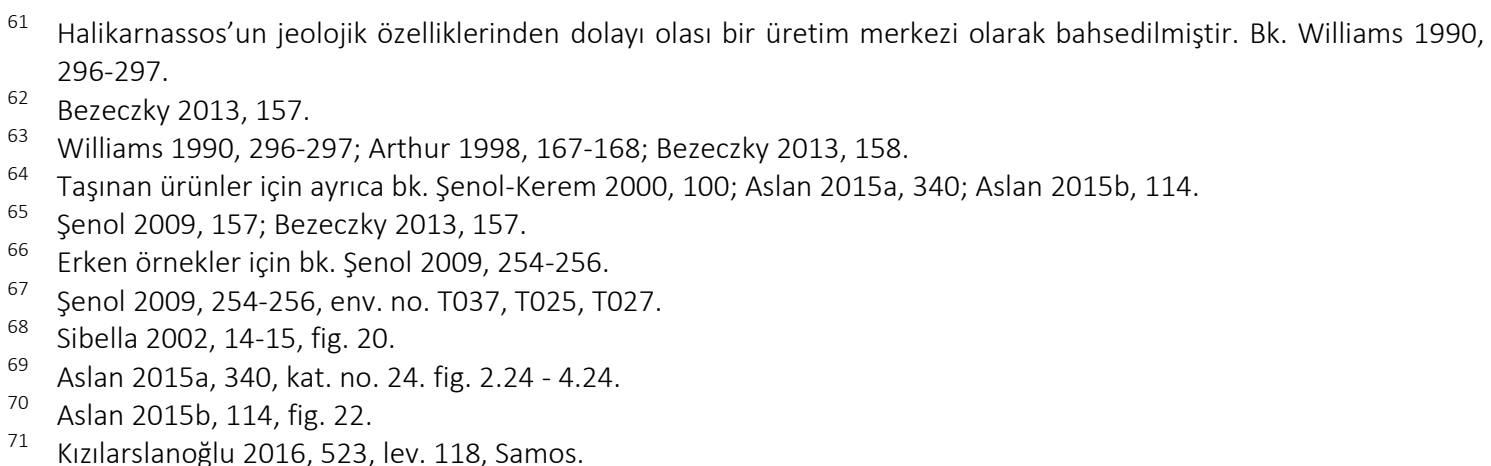


Sebaste'de ele geçen benzerlerinden dolayı MS VI. yüzyıl sonu VII. yüzyıl başlarına önerilmekte$\operatorname{dir}^{73}$ (Fig. 7).

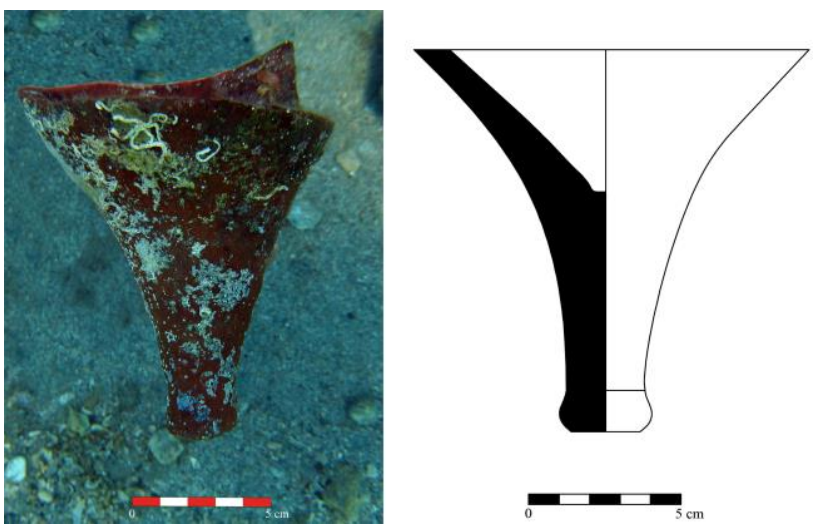

Fig. 7. Samos Cistern (Sarnıç) Tipi Amphora

\section{Günsenin (Ganos) Amphoraları}

Günsenin (Ganos) tip I amphoralarının literatürde birden fazla isimle anılmaktadır ${ }^{74}$. Yapılan çalışmalarla kökeninin Marmara Denizi'nin kuzey batısında Gaziköy ve Hoşköy olduğu düşünülmektedir75. Oldukça geniş yayılım gösteren bu tip amphoralar, özellikle Karadeniz'in batısında bulunan merkezlere yoğun olarak ihraç edilmiş olup Ege ve Akdeniz kıyılarında bulunan merkezlerde de söz konusu amphoralar ele geçmiştir ${ }^{76}$. Tespit edilen bu tip amphoraların üzerinde kısaltmaların yer aldığı mühürler bulunmuştu. Özellikle MS IX. yüzyılın sonları ile MS 12. yüzyıl arasına tarihlenen tabakalarda ele geçen Günsenin (Ganos) amphoralarının üzerindeki kısaltmaların Bizans Imparatorları ve ailelerinin isimleri olduğu yorumu getirilmiştir77. Bu kısaltmalar vasıtası ile de dönemin İmparatoru tespit edilerek amphoranın tarihlendirilmesi sağlanmıştır. Günsenin (Ganos) amphoralarında ihraç ürünü olarak ise, yapılan analizler sonucunda, şarap taşınmış olabileceği ve şarap dışında da farklı ürünler taşındığı düşünülmektedir78.

Çalışmamızda Phaselis Güney Liman Alanında formu tespit edilebilen beş adet Günsenin (Ganos) amphorasına rastlanmıştır. Farklı tiplere ait bu amphora formlarından dört tanesi tip I sınıfının farklı versiyonları olarak karşımıza çıkmaktadır. Ayrıca Günsenin (Ganos) amphora formları içerisinde bir adet de tip IV grubunun "b" alt formu olduğu tespit edilmiştir (Fig. 8-9).

\section{Günsenin (Ganos) Tip I Amphoraları}

Çalışmamızda dört adet tespit edilen ve Tip I sınıfı içerisinde değerlendirilen Günsenin (Ganos) amphoralarının, ağız, boyun, kulplar ve gövdenin bir kısmı günümüze kadar sualtında korunabilmiştir. Bu tip amphoralara form olarak bakıldığında; ucu yuvarlatılmış ağız kenarına, kısa, dar, konik bir boyun yapısına, ağızın hemen altından başlayarak omuzda birleşen oval kesitli sağlam, kalın kulplara, omuzda genişlemeye başlayan geniş yivli bir gövdeye ve düz dibe sahiptirler.

\footnotetext{
Bezeczky 2013, 157.

Benzer dip yapısına sahip Samos Cistern (Sarnıç) tipi amphoralar için bk. Arthur 2005, Samos Cistern Type.

Diğer isimleri için bk. Hayes 1992 Tip 54.

Günsenin 1993, 193-198.

Günsenin 1999, 19, fig. 3.

Şenol 2009, 163, dn. 587.

Doorninck 1989, 256.
} 


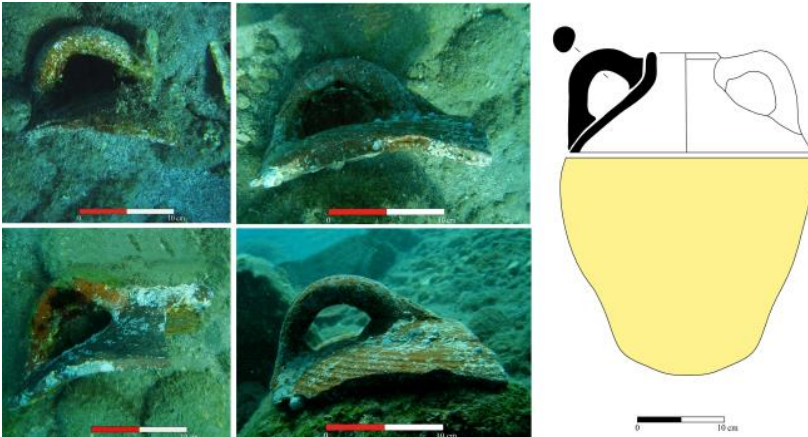

Fig. 8. Günsenin (Ganos) Tip I

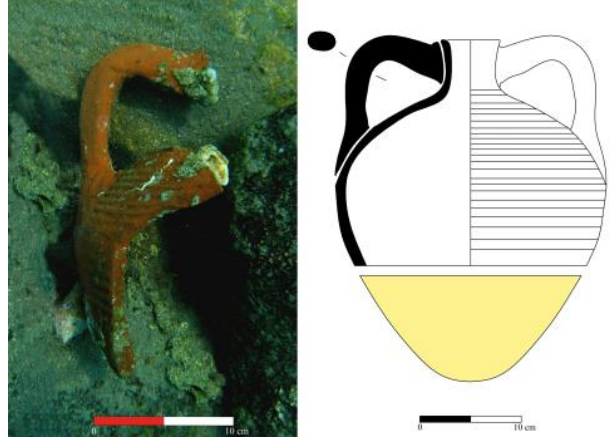

Fig. 9. Ganos(Günsenin) Tip IV

Üretildiği dönemlerde oldukça geniş bir dağılım gösteren bu amphoralar79, Karadeniz'de bulunan merkezler başta olmak üzere, Anadolu'nun güney ve batı kıyıları, Ege'de bulunan merkezler, İtalya ve Adriyatik kıyılarına kadar ihraç edildiği görülmektedir80.

Yapılan kazılardan ele geçen benzer örnekleri incelendiği zaman, İstanbul Saraçhane kazılarında MS X. ve 11. yüzyıla81, Kadıkalesi/Anaia'da ele geçen örnekler MS X. yüzyılın ortası ile MS 13. yüzyıl arasına tarihlendirilmiştir82. Batıklardan ele geçen örnekler, Hayırsızada batığında MS 10. yüzyıla83, Serçe Limanı batığı ve Tekmezar 1 batığı'nda MS 11. yüzyıla ${ }^{84}$, Sudak koyu'nda gerçekleştirilen sualtı çalışmalarında MS 11. yüzyıl tarihi önerilmiştir85. Ayrıca Marmaris Müze'sinde MS X. yüzyıl sonu 12. yüzyıl başına ${ }^{86}$, Bodrum Müzesi'nde bulunan benzeri MS 11 13. yüzyıl aralığına87, Side Müzesi'nde MS IX. ve 11. yüzyıl aralığına88, Arslan Eyce Taşucu Amphora Müzesi'nde en erken örneği MS X. yüzyılın ortalarından başlayarak MS 11. yüzyıla kadar ki örnekler89 ve Mersin (İçel) Müzesi'nde MS 11-13. yüzyıl aralığı önerilmektedir90. Çalışmamızda yer alan dört adet Günsenin (Ganos) tip I amphoraları için ise MS 11.-12.yüzyıl aralı̆̆ı önerilmektedir91 (Fig. 8).

\section{Günsenin (Ganos) Tip IV Amphorası ${ }^{92}$}

Karadeniz'deki merkezlerde ${ }^{93}$ ve özelliklede Akdeniz kıyılarında sıklıkla rastlanan bu tip amphoralar ayrıca Dalmaçya kıyılarında, Puglia, Barletta, Ege, Atina, Çanakkale ve Italya kıyılarında tespit edilmiştir94. Phaselis Güney Liman Alanı'nda tespit edilen Günsenin (Ganos) Tip IV

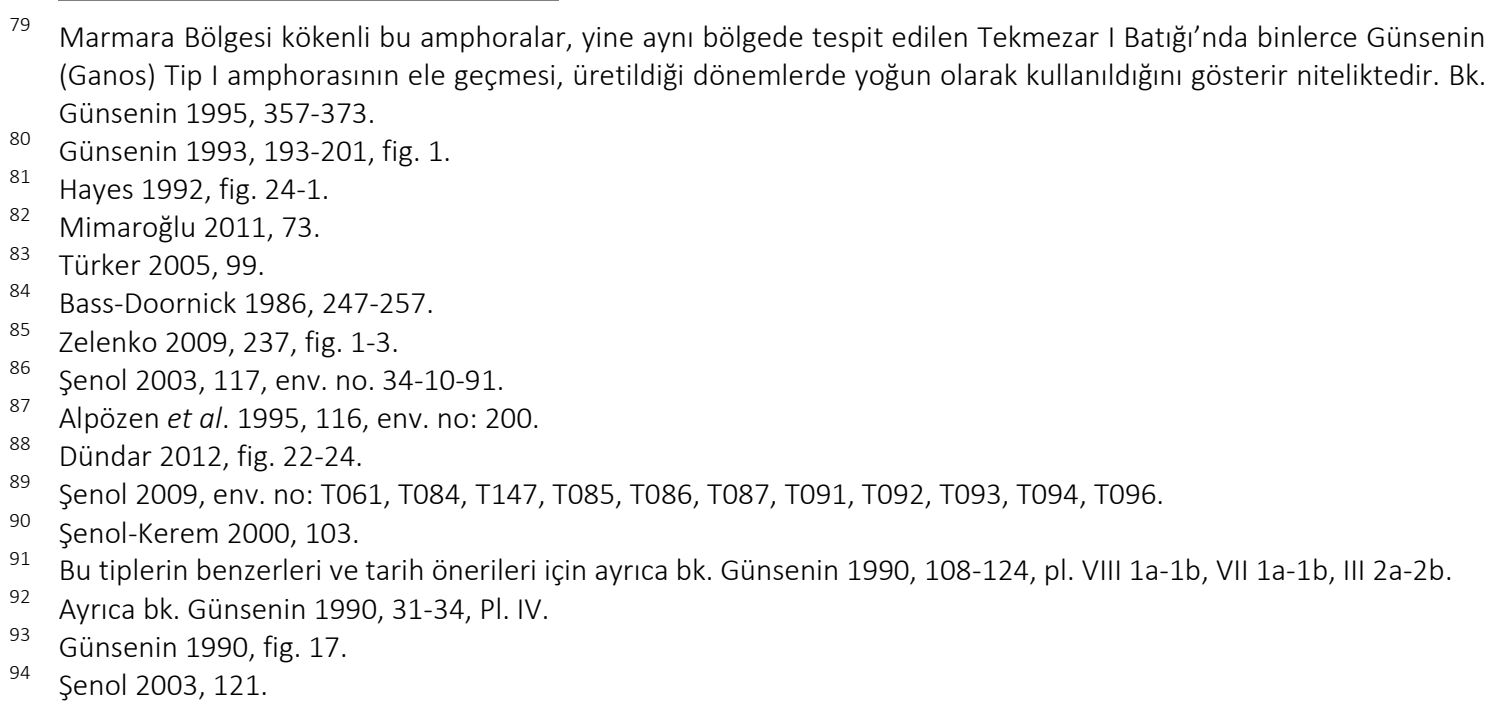


amphorasının, kulp ve gövdenin bir kısmı günümüze kadar koruna gelmiştir. Form olarak, dışa çekik ucu yuvarlatılmış ağız kenarına, dar boyna, boynun üst bölümünden başlayarak ağız kenarı seviyesini aşan ve omuzda gövdeye birleşen oval kesitli kalın kulplara ve dibe doğru daralan ovoidal gövdeye ve ayrıca kaideden ağız kenarına kadar yivlere sahiptir.

Çalışmamızda münferit şekilde tespit edilen Günsenin (Ganos) tip IV amphorasının benzeri; Demre-Myra Aziz Nikolaos Kilisesi kazısında MS 11.-12. yüzyıla, Saraçhane kazılarında MS 12.-13. yüzyıla95, Kadıkalesi/Anaia kazısında MS 12.-13. yüzyıla tarihlendirilmiştir ${ }^{96}$. Bulgaristan'da Khersones, Neseber ve Balaklava ve Sırbıstan'da Danubian'da yapılan kazılarda ele geçen benzer tipli amphoralar için MS 12. ve 13. yüzyıl aralığı önerilmiştir97. Tekirdağ, Sinop ve Samsun Müzesi'nde 12. ve 13. yüzyıla98, Marmaris Müzesi'nde MS IX.-11. yüzyıl aralığına99, İçel Müzesi'nde MS 12.-14. yüzyıllara100 ve Çamaltı Burnu Batığı'nda MS 13. yüzyıla101 tarihlendirilmiştir. Çalışmamızda tespit edilen Günsenin (Ganos) Tip IV amphorası için benzerlerinden yola çıkarak MS 12.-13. yüzyıl aralığı önerilmektedir102 (Fig. 9).

\section{Değerlendirme}

Güney Liman Alanı'nda 2016'da başlanan sualtı araştırmaları 2018 yılında da sürdürülmüş olup çok sayıda buluntu tespit edilerek belgelenmiştir. Bu kapsamda yukarda anlatılan amphoralar ana materyal olarak belirlenmiş ve form ile köken incelemeleri yapılarak benzerleriyle karşılaştırılarak tarih önerilerinde bulunulmuştur. Beş farklı bölgeye ait olduğu tespit edilen bu yedi amphora formunun en erken örneğini Mısır kökenli AE 1-A amphorası oluşturmaktadır. MÖ III. yüzyılın son çeyreği ile MÖ II. yüzyılın ilk çeyreğine tarihlenen söz konusu amphora, Phaselis Güney Liman Alanı'nda sualtında yapılan çalışmaların en erken tarihli buluntusudur. Ayrıca AE 1 amphoraları, üretildiği dönemlerde bölgesel bir dağılım göstermiş ve sınırlı sayıda ele geçmiştir. Bu amphoranın bir örneği, Taşucu Arslan Eyce Amphora Müzesi'nde bir başka örneği ise Nagidos'ta bulunmaktadır ve Phaselis Güney Liman Alanı'nda bir başka örneğin tespit edilmesi ayrıca önem arz etmektedir. Nitekim benzer bir durum Kilikya kökenli, küçük boyutlarda üretilen ve sınırlı sayıda ele geçen M 239 tipi amphora için de geçerlidir. MS IV. yüzyıl ortalarına tarihlenen bu tip amphoranın bir örneği Silifke Müzesi'nde bir diğer örneği ise Mersin Müzesi'nde bulunmaktadır.

Sözü edilen AE 1 ve M 239 tipi amphoranın yanı sıra MS II. yüzyıl sonu III. yüzyıl başlarına tarihlenen Afrika II-A, MS V. yüzyıla tarihlenen LR 1-A, MS VI. yüzyıl sonu VII. yüzyıl başlarına tarihlenen Samos Cistern (Sarnıç), MS 11.-12. yüzyıl arasına tarihlenen Günsenin (Ganos) tip I ve MS 12.-13. yüzyıla tarihlenen Günsenin (Ganos) tip IV amphoraları Güney Liman Alanı'nda tespit edilen diğer amphoralardır. Ayrıca geçmiş yıllarda Güney Liman Mendireğinde yapılan çalışmalarda da beş farklı kökenden altı farklı amphora tipi tespit edilmiştir103. Önceki çalışmalarla birlikte bu alanda sekiz farklı kökenden on üç farklı amphora tipi tespit edilmiştir. Kökenlerine bakıldığı zaman, üç adet Kilikya, üç adet Mısır, iki adet Ege, iki adet Marmara ve birer adet

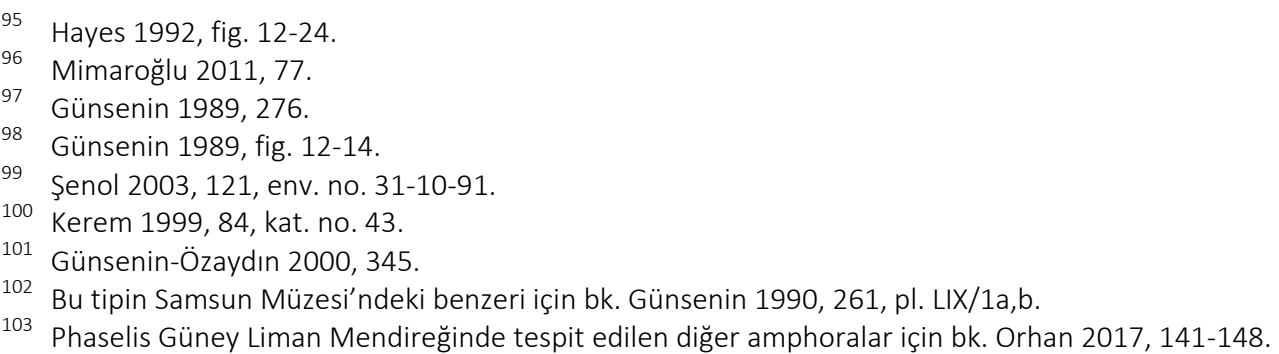


Tunus, Tripolitania ve Gaza bölgelerine ait amphoralar olduğu ortaya çıkmaktadır. Bu kapsamda ticari amphoralar sayesinde uzun yıllar boyunca Phaselis Güney Liman Alanı́nın ticari fonksiyonun devam ettiği, geniş bir coğrafyaya yayılan deniz ticaretine ev sahipliği yaptığı söylenebilmektedir104.

\section{BIBLIYYOGRAFYA}

ADALYA

AJA

Alkaç 2013

Alpözen et al. 1995

Arslan et al. 2013

Arslan 2018

Arslan-Tüner Önen 2013

Arslan-Tüner Önen 2018

Arthur 1998

Arthur 2005

Aslan - Baybo 2015

Aslan 2015a

Aslan 2015b

Aslan 2016

Aslan et al. 2018

AST

Autret et al. 2010

Ballet 1995

BAR

BARIntSer

Bass-Doorninck 1986
Annual of the Suna \& Inan Kiraç-Research Institute on Mediterranean Civilizations.

American Journal of Archaeology.

E. Alkaç, "Silifke Müzesinden Doğu Akdeniz Üretimi Amphoralar". Cedrus I, (2013), 107-124.

O. Alpözen - A. H. Özdaş - B. Berkaya, Bodrum Sualtı Arkeoloji Müzesi Ticari Amphoraları. Ankara 1995.

M. Arslan, K. Demirtaş - N. Tüner Önen, "Phaselis ve Teritoryumu Yüzey Araştırması 2012". Anmed 11 (2013) 224-229.

M. Arslan, "Phaselis ve Teritoryumunun Yol ve Savunma Sistemleri: TekirovaÇamyuva Arası". Phaselis IV (2018) 15-47.

M. Arslan - N. Tüner Önen, "2012 Yılı Phaselis Antik Kenti ve Teritoryumu Yüzey Araştırması". AST 31/1 (2013) 78-89.

M. Arslan - N. Tüner-Önen, "Phaselis, 2017 Yüzey Araştırmaları ve Kazı Çalışmaları". Phaselis IV (2018) 295-323.

P. Arthur, "Eastern Mediterranean amphorae between 500 and 700: a view from Italy." Ceramica in Italia. All'insegna del giglio (1998) 157-184.

P. Arthur, Samos Cistern Type, in: S. Keay - D. F. Williams, Roman amphorae. A digital resource (University of Southampton 2005). Kaynak: http://archaeologydataservice.ac.uk/archives/view/amphora_ahrb_ 2005/

E. Aslan - S. Baybo, "Phaselis Kent Limanları ve Sualtı Araştırmalarının Ön Değerlendirmesi". Phaselis I (2015) 1-17.

E. Aslan, "Kekova Adası 2012-2013 Yılı Sualtı Araştırmalarında Bulunan Amphoraların Tipolojik Değerlendirmesi". OLBA XXIII (2015) 321-369.

E. Aslan, "2014 Yılı Knidos Sualtı Araştırmaları’nda Elde Edilen Illk Bulguların Değerlendirilmesi". MJH V/I (2015) 101-123.

E. Aslan, "Phaselis Merkezi (Kent) Limanı". Phaselis II (2016) 31-47.

E. Aslan- Y. Kılıç - U. Orhan, "Phaselis Güney Limanı" Phaselis IV (2018) 1-13. Araşıırma Sonuçları Toplantısı.

C. Autret - R. Yağcı - N.K. Rauh, "Soli/Pompeipolis'te LRA 1 Amphora Fırın Alanı". ANMED 8 (2010) 203-207.

P. Ballet, "Relations céramiques entre l'Égypte et Chypre à l'epoque grécoromaine et byzantine". In Hellenistic and Roman Pottery in the Eastern Mediterranean-Advances in Scientific Studies, Acts of the II Nieborów Pottery Workshop, Warsaw 18-20 December 1995. Warsaw (1995) 11-25.

British Archaeological Reports.

British Archaeological Reports. International Series.

G. F. Bass - F. H. Van Doorninck, Yassıada I. A Seventh Century Byzantine

104 Güney Liman için ayrıca bk. Aslan-Baydo 2015, 1-17; Tüner-Önen 2015, 24-31. 
$\mathrm{BCH}$

Bezeczky 2013

Bonifay 2004

CahCerEg

Doorninck 1989

Durukan 2015

Dündar 2012

Empereur-Picon 1989

Empereur-Picon 1998

Gibbins 2001

Günsenin 1989

Günsenin 1990

Günsenin 1993

Günsenin 1995

Günsenin 1999

Günsenin-Özaydın 2000

Hayes 1992

HESPERIA

IJNA

Keay 1984

Kerem 1999

Kızılarslanoğlu 2016

KST

Majcherek-Shennawi 1992

Mimaroğlu 2011
Shipwreck. Texas 1982.

Bulletin De Correspondance Hellénique.

T. Bezeczky - P. Scherrer - R. Sauer, The amphorae of Roman Ephesus. Verlag der Österreichischen Akademie der Wissenschaften 2013.

M. Bonifay, Etudes sur la céramique romaine tardive d'Afrique. Oxford 2004. Cahiers De La Céramique Égyptienne.

F. H. Van Doorninck, "The Cargo Amphoras on the $7^{\text {th }}$ Century Yassı Ada and $11^{\text {th }}$ Century Serçe Limanı Shipwrecks: Two Examples of a Reuse of Byzantine areas Transport Jars". BCH XVIII (1989) 247-257.

M. Durukan, “Geç Antik Çağ'da Doğu Akdeniz'deki Ekonomik Gelişmenin Nedenleri: Ijpek Yolu ve Baharat Yolu'nun Rolü, LR1 Amphoraları ve Kilikia'daki Diğer Kanıtlar". ADALYA XVIII (2015) 241-253.

E. Dündar, Patara Kazılarından Ele Geçen (1989 - 2010 Yılları) Arkaik, Klasik ve Hellenistik Dönem Ticari Amphoralar ve Amphora Mühürleri. Yayınlanmamış Doktora Tezi, Akdeniz Üniversitesi. Antalya 2012.

J. Y. Empereur - M. Picon, "Les régions de production d'amphores impériales en Méditerranée Orientale". Publications de l'École Française de Rome 114.114 (1989) 223-248.

J. Y. Empereur - M. Picon, "Les ateliers d'amphores du lac Mariout". BCH Suppl. 33. (1998) 75-91.

D. Gibbins, "A Roman shipwreck of c. AD 200 at Plemmirio, Sicily: evidence for North African amphora production during the Severan Period". World Archaeology, 32,3 (2001) 311-334.

N. Günsenin, "Recherches sur les amphores Byzantines dans les musees turcs". Eds. V. Deroche, J. M Spieser, BCH Suppl, XVIII. (1989) 267-276.

N. Günsenin, Les amphores Byzantines (Xe-XIIle siècles): typologie, production, circulation d'après le collections turques. PhD Diss., Paris Université. Paris 1990. N. Günsenin, "Ganos. Centre de production d'amphores a I,epoque Byzantine" Anatolia antiqua Eski Anadolu 2/1 (1993) 193-201.

N. Günsenin, "1994 Yılı Marmara Adalar Sualtı Araştırması". AST XIII, Cilt I (1995) 357-373.

N. Günsenin, "From Ganos to Serçe Limanı". The INA Quarterly, 26.3 (1999) 18-21.

N. Günsenin - N. Özaydın, "Marmara Adası Çamaltı Burnu Batığı 1998", KST XXI.2 (2000) 341-350.

J. W. Hayes, Excavations at Saraçhane İstanbul 2 The Pottery. Princeton 1992. Journal of the American School of Classical Studies at Athens.

The International Journal of Nautical Archaeology and Underwater Exploration. S. J. Keay, Late Roman Amphorae in the Western Mediterranean: a typology and economic study. The Catalan evidence. BAR Suppl. 196(i). Oxford 1984.

F. Kerem, içel Müzesi'nde bulunan Bir Grup Amphora. Yayınlanmamış Yüksek Lisans Tezi, Hacettepe Üniversitesi. Ankara 1999.

H. A. Kızılarslanoğlu, Antik Çağ'da Elaıussa Sebaste'nin Amphora Üretimi ve Ticari Iliş̧kileri. Yayınlanmamış Doktora Tezi, Atatürk Üniversitesi Sosyal Bilimler Enstitüsü. Erzurum 2016.

Kazı Sonuçları Toplantısı.

G. Majcherek, - A. A. El-Shennawi, "Research on amphorae production on the northwestern coast of Egypt". CahCerEg III (1992) 123-136.

S. Mimaroğlu, "Kadıkalesi/Anaia Bizans Dönemi Amphoraları". Sanat Tarihi Dergisi XX/1 (2011) 63-92. 
MJH

OLBA

Orhan 2017

Orhan 2018

Panella 1973

Peacock-Williams 1986

Pieri 1998

Rauh 1998

Rauh et al. 2006

Riley 1979

Robinson 1959

Sciallano - Sibella 1991

Sibella 2002

Slane 1994

Şenol - Alkaç 2017

Şenol - Kerem 2000

Şenol 2000

Şenol 2003

Şenol 2008

Şenol 2009

Şenol 2010

Şenol-Aşkın 2007

Şenol-Şenol 2003

Tüner Önen 2008
Mediterranean Journal of Humanities.

Mersin Üniversitesi Kilikya Arkeolojisini Araştırma Merkezi yayınları.

U. Orhan, "Phaselis 2016 Yılı Güney Limanı Amphora Buluntuları". Phaselis III (2017) 141-148.

U. Orhan, Kekova Sualtı Araştırmalarında Tespit Edilen Amphoralar. Yayınlanmamış Yüksek Lisans Tezi, Selçuk Üniversitesi Sosyal Bilimler Enstitüsü. Konya 2018.

C. Panella, "Appunti su un gruppo di anfore della prima, media e tarda eta imperiale". OSTIA III (1973) 460-633.

D. P. S. Peacock - D. F. Williams, Amphorae and the Roman Economy: An Introductory Guard. London 1986.

D. Pieri, "Les importations d'amphores orientales en Gaule Méridionale durant l'antiquité tardive et le haut-moyen age (IVe-VIle siècles aprés J.-C.) Typologie, chronologie et contenu". SFECAG, Actes du Congrés d'Istres, (1998) 97-105.

N. K. Rauh, "Dağlık Kilikya Yüzey Araştırma Projesi: 1997 Sezonu Raporu”. AST XVI.I (1998) 339-348.

N. K. Rauh - M. J. Dillon - C. Dore - R. Rothaus - M. Korsholm, "Viticulture, Oleoculture and Economic Development in Roman Rough Cilicia". Münstersche Beiträge zur antiken Handelsgeschichte XXV/I (2006) 49-98.

J. A. Riley, "The coarse pottery from Berenice". Eds. J. A. Lloyd, Excavations at Sidi Khrebish, Benghazi (Berenice), Vol. II. Tripoli (1979) 91-497.

H. Robinson, Pottery of the Roman Period: Chronology. Princeton 1959. M. Sciallano - P. Sibella, Amphores Comment les Identifier?. Errance 1991. P. Sibella, "The George McGhee Amphora Collection at the Alanya Museum, Turkey". The INA Quarterly vol. 29, suppl. 1 (2002) 3-19.

K. W. Slane, "Tetrarchic Recovery in Corinth: Pottery, Lamps, and Other Finds from the Peribolos of Apollo". Hesperia 63, 2 (1994) 127-168.

A. K. Şenol - E. Alkaç, "The rediscovery of an LR 1 workshop in Cilicia and the presence of LRA 1 in Alexandria in the light of new evidence". LRCW 5 Vol. II (2017) 831-844.

A. K. Şenol - F. Kerem, "İçel Müzesinde Bulunan Bir Grup Amphora". OLBA III (2000) 81-114.

A. K. Şenol, İskenderiye Kazılarında Ele Geçen Amphoralar Işığında Kentin Roma Dönemi Şarap, Zeytinyağı, Salamura Balık ve Sosyal Ticareti. Yayınlanmamış Doktora Tezi, Ege Üniversitesi. İzmir 2000.

A. K. Şenol, Marmaris Müzesi Ticari Amphoraları. Ankara 2003.

A. K. Şenol, "Cilician Commercial Relations with Egypt due to the New Evidence of Amphora Finds". OLBA XVI (2008) 109-131.

A. K. Şenol, "AETAM'da Bulunan Amphoraların Tipolojisi". Eds. A. K. Şenol, AETAM'da (Arslan Eyce Taşucu Amphora Müzesi) Bulunan Ticari Amphoralar ve Akdeniz'de Ticaretin İzleri. Mersin (2009), 100-319.

A. K. Şenol "Hellenistik Dönem'de Mısır'da Amphora Üretimi". OLBA XVIII, (2010) 141-173.

A. K. Şenol - E. Aşkın, "Amphoralar Işığında Kentin Ticari Iliş̧kileri”. Eds. S. Durugönül, Dağlık Kilikia'da Bir Antik Kent Kazısının Sonuçları: Nagidos ADALYA Suppl. VI. Antalya (2007) 241-297.

G. C. Şenol - A. K. Şenol, "Commercial Ties of Cilicia by Means of Hellenistic and Roman Amphorae". OLBA VII (2003) 119-143.

N. Tüner Önen, Phaselis Antik Kenti ve Teritoryumu. Yayımlanmamış Doktora 
Tüner Önen 2015

Türker 2005

Williams 1990

Williams-Carreras 1995

Zelenko 2009

Zemer 1977
Tezi, Akdeniz Üniversitesi. Antalya 2008.

N. Tüner Önen, "Yeni Buluntular Işı̆̆ında Phaselis Epigrafi Çalışmaları". Phaselis I (2015) 19-38.

A. Ç. Türker, "Bizans Dönemi Demre-Myra Sırsız Seramik Buluntuları". ADALYA IX (2006) 155-169.

D. F. Williams, "A note on the petrology of a Samos Cistern Type amphora from excavations at the Castello di Udine". Aquileia Nostra 61 (1990) 296 vd.

D. Williams - C. Carreras, "North African amphorae in Roman Britain: a reappraisal". Britannia XXVI (1995) 231-252.

S. Zelenko, "Shipwrecks of the 9th-11th centuries in the Black Sea near Soldaya". In Actas del VIII Congreso Internacional de Cerámica Medieval TOMO I. Ciudad Real (2009) 235-244.

A. Zemer, Storage Jars in Ancient Sea Trade. Haifa 1977. 